\title{
EDUCATIONAL PSYCHOLOGY
}

\section{Dependence of success in foreign language acquisition at primary school age on reaction type and cognitive control}

\author{
Elena N. Bicherova
}

Psychology and Pedagogy Faculty, Petrovski Bryansk State University, Bryansk, Russia

Corresponding author. E-mail: bic-elena@yandex.ru

Background. This article reveals the importance of studying the problem of success in foreign language acquisition during the first stage of study in the modern educational environment. Particular attention is paid to factors of successful foreign language acquisition during the primary-school ages, which depends on cognitive style features, such as reaction type and cognitive control. The content and characteristics of cognitive styles as individual styles of foreign language acquisition are analyzed in the context of a leading activity of primary school students.

Objective. A hypothesis of this research was that success in foreign language acquisition depends on reaction type and cognitive control, particularly the extent of the cognitive styles of impulsivity, reflexivity, rigidity and flexibility in primary-school students.

Design. To implement the proposed empirical tasks, the author organized and conducted research using a combination of methods intended to study the correlation between success in foreign language acquisition by primary-school students and reaction type as well as the features of cognitive control. A total of 74 elementary-school pupils aged 8-11 years were studied. A direct connection between success in foreign language acquisition and the indicators of the cognitive style "impulsivity - reflexivity" was identified using mathematical statistics methods.

Results. This study found no statistically significant correlation between success in foreign language acquisition and the indicators of the cognitive style "rigidity - flexibility". Therefore, the results confirm that success in foreign language acquisition at primary-school ages is determined more by reaction type (impulsive or reflexive) than by the features of cognitive control (rigidity or flexibility).

Conclusion: The practical significance of the study is that the obtained results can be used in the work of teachers and psychologists to improve the educational process in primary school and to promote the effective study of foreign language by students.

Keywords: cognitive style, reaction type, cognitive control, impulsivity, reflexivity, rigidity, flexibility, success in foreign language acquisition, primary-school age 


\section{Introduction}

Increasing attention is being paid to foreign language teaching in primary school, which is important for state educational policy. Earlier foreign language acquisition has a positive effect on the formation of personality and the overall development of the child in support of such mental and physiological characteristics as curiosity, the need for communication, the ability to mimic, and the ability to articulate, thereby promoting the development of a personal emotional relationship of the child with the foreign language.

According to I. Zimnyaya and Z. Klychnikova, early foreign language teaching gives the child an opportunity to study the language intensively during a long period of time and, in general, positively influences the activity of learning (Zimnyaya, 1991, 2008; Klychnikova, 1973). The activity of learning, which is diverse in content and complex, leads to the production of different styles of intellectual activity (Kulyutkin \& Sukhobskaya, 1971).

The study of the features of the activity of learning and the processes of conceptualization at primary-school age shows that cognitive styles, as factors of individual regulation, play a significant regulative role in the formation of intellectual strategies (Klaus, 1987).

The concept of "cognitive styles" includes a variety of individual characteristics of cognitive activity during personality development (Kagan, 1966; Witkin \& Goodenough, 1981). Klaus examines the cognitive component of the activity of learning and analyzes the individual characteristics of information perception, processing, storage and utilization. Klaus also emphasizes differences in pupils' personal characteristics, such as gender, age, features of cognitive style and achievement motivation. "The cognitive styles appear as soon as the person addresses the situation, in which he has not adopted the way of behavior yet, or where a personal 'contribution' is needed to solve the problem: the personal activity" (Klaus, 1987, p. 56). According to Klaus, the most important feature of cognitive styles is the fact that they result in the learning process, and it is necessary to take them into account in the individualization of the pupil's learning (Klaus, 1987, pp. 41-78).

A review of the works of the Russian researchers who address the problem of cognitive styles and linguistic competence in the activity of learning (e.g., E.V. Artsishevskaya, S.V. Boldyreva, E.P. Gustova, M.K. Kabardov, Ya.A. Tunkun, I.L. Zhirnova et.al) as well as an analysis of psychological theories and concepts (A. Adler, J. Bruner, J. Kagan, R. Solso, H.A. Witkin, V.A. Kolga, A.A. Leontiev, I.S. Yakimanskaya, V.N. Druzhinin, V.P. Zinchenko, I.A. Zimnyaya, M.A. Luria, M.A. Kholodnaya) demonstrates the timeliness of the question under discussion.

The relevance of this study is primarily based on the presence of vexing questions concerning the study of cognitive styles in conjunction with the individual ways a person uses the acquisition of new information and the handling of obtained data (Averin, Kireeva, \& Kotova, 2014; Barabanshhikov, Nosulenko, \& Samojlenko, 2011, etc.). This issue becomes especially significant for the subjectsubject approach to foreign language teaching in primary school (Ilyin, 2011; Protasova, 2011, Nikitenko, 2011; Shchukin, 2010, etc.).

Since the individual style of foreign language acquisition can be considered the success factor for foreign language acquisition (Boldyreva, 2004; Kabardov, 1983, 2001), one may state that the formation of cognitive style contributes to effective 
foreign language teaching. Therefore, it becomes necessary to study the correlation between success in foreign language acquisition and the features of cognitive styles. This research also has great importance because foreign language teaching is one of the most promising endeavors in the modernization of elementary education. The scientific novelty of the present work lies in the study of the orientation of correlations 1) between success in foreign language acquisition by primary-school students and reaction type (the cognitive styles of impulsivity and reflexivity) and 2) between success in foreign language acquisition by primary-school students and the features of cognitive control (rigidity and flexibility).

Before presenting the empirical part of this work, it is necessary to review the key concepts of the problem.

In both Russian and foreign psychology, there are a great number of works dedicated to the study of cognitive styles (Witkin, Moore, Goodenough, \& Cox, 1977; Kolga, 1976; Holodnaja, 2004). Some researchers use concepts that form a semantic field with the concept of the cognitive style, such as "lifestyle" (Adler, 2002), "rigidity" (Cattell, 1971), "control rigidity" (Stroop, 1935), and the concept of balance between the first and second signal systems (Pavlov, 1951).

A. Adler used the concept of cognitive style to define such personal characteristics as the individual features of the cognitive processes that predetermine the utilization of different research strategies. In his scheme of individual psychology, the cognitive style is the peculiarity of the personal way of living, structured by goal-setting and achievement (Bunduls, 1982).

Cognitive styles are relevant to operating style because all of them characterize the typical features of intellectual activity, including perception, thought and action, which are connected to the solution of cognitive tasks, particularly in situations of uncertainty (Klaus, 1987).

At the present time, there is no consensus concerning the content and the meaning of the concept of cognitive style. However, this concept may turn out to be very useful in pedagogical psychology, where cognitive style can be considered to be educational style (Kolga, 1976).

In his book, G. Klaus describes the regulative functions of two the most popular and well-known cognitive styles that occur in the process of teaching: "field dependence - field independence" and "impulsivity - reflectivity". The intensity of each of these bipolar styles influences the strategy of pupils' perceptions, their conceptual sphere and the development of reasoning. "Like other cognitive styles, they are: 1) stable towards the age group the individual belongs to; 2) relatively independent of the person's motivation and goal intentions. They demonstrate another personal characteristic of cognition" (Klaus, 1987, p.78).

According to Klaus, "the intensity of the cognitive styles changes during the ontogenetic development but stays the same in...each particular person, if we compare his characteristics with those of the age group he belongs to" (Klaus, 1987, p. 91).

The idea of the existence of stable differences in ways of perception and thinking was suggested by G. Klein (1970), and the concept of "cognitive style" was proposed by the American psychologist R. Gardner (1953). Cognitive style as a stable individual characteristic of personal interconnection with the information field, connected to different aspects of cognitive-sphere functioning, was studied by $\mathrm{H}$. 
Witkin (Witkin et al., 1977). The analysis of the sources showed that the most frequently explored parameters of cognitive styles are 1) the type of perception: field dependence - field independence (Witkin, 1949);2) the type of reaction: impulsivity - reflexivity (Kagan, 1966);3) the type of thinking: analyticity - syntheticity (Gardner, Holzman, Klein, Linton, \& Spence, 1959); 4) the equivalence range: narrowness - largeness of the categorization (Pettigrew, 1958); and 5) the degree of complexity: cognitive complexity - simplicity (Bieri, 1955). "However, the first results have already shown that the researchers deal with the psychological reality, analysis of which can not be limited by the understanding of the style only as the cognitive variable" (Libin, 1999, p.163).

There are other cognitive styles described in native and foreign sources, such as 1) the features of cognitive control: rigidity - flexibility; 2) the predominant method of information processing: figurative - verbal; and 3) the locus of control: external - internal (Holodnaja, 2004, p.122).

The mental activity of learning varies in content and complexity and leads to the emergence of different styles of intellectual activity. The study of the intellectual activity involved in decision-making in situations of uncertainty distinguishes the styles according to the reaction type (reflexivity and impulsivity) when it is necessary to make the right choice from several alternatives. Impulsive people tend to respond to a problem quickly, making decisions without thorough thinking. In contrast, reflexive people can be characterized by delayed reaction in such situations, making a decision only after thorough consideration of all pros and cons. They collect more information before the answer, use more effective ways of problemsolving, and utilize strategies acquired in the learning process more successfully (Kagan, 1966).

According to the data of S. Messick (1984), response rate does not depend on intelligence level, unlike the number of incorrect decisions.

In terms of the type of cognitive control, psychologists emphasize such cognitive styles as rigidity and flexibility. These styles are connected with the simplicity or complexity of changing work methods or changing from one information alphabet to another. The complexity of the change leads to the narrowness and inflexibility of the cognitive control (R. Kettell, J. Stroop).

The cognitive styles discussed above become especially important in the situation of foreign language study, when mental flexibility and a rapid rate of response to the new stimuli are needed. Therefore, to learn a foreign language successfully, it is necessary to have characteristics such as communicative activity, a focus on the language behavior and language system, and fluency in solving linguistic tasks. In view of this understanding, there are two styles (types) of language acquisition: communicative (typical of people with high nervous system lability) and linguistic (typical of inactive people) (Kabardov, 1983).

\section{Method}

The main goal of this research is to define the correlation between success in foreign language acquisition by primary-school students and cognitive styles that vary by the type of reaction and the features of the cognitive control. For this purpose, an empirical study was organized and conducted. 
Participants. A total of 74 elementary school pupils aged 8-11 years were studied. The sample group included 24 second-form pupils aged 8-9, 25 third-form pupils aged $9-10$ and 25 fourth-form pupils aged $10-11$ years.

Measures and procedure. To examine the problem, the author used the following diagnostic test instruments: "A comparison of similar pictures" (J. Kagan), "Stroop interference" (J. Stroop), and "evaluation of the level of the foreign language acquisition" (E. Bicherova, N. Volchkova).

The "comparison of similar pictures" method is used to diagnose the cognitive style of the reaction type "impulsivity - reflexivity". According to a tentative assumption by J. Kagan, this cognitive style characterizes individual differences by the tendency to make decisions quickly or slowly. This style becomes especially significant in conditions of uncertainty, when it is necessary to make the right choice from several alternatives (Kagan, 1966).

The procedure. The subject is shown 2 training and 12 main papers with an image of a known object (a reference figure) on the top and 8 almost identical images of the same object in two rows at the bottom, where only one image is identical to the reference figure. The subject's instruction is to find and point to the image that is identical to the reference figure.

People with the impulsive style make assumptions in the situation of alternative choice promptly but make many errors. A slow rate of decision-making is typical of people with the reflexive style; they make few mistakes due to their thorough preliminary analysis.

To determine the type of cognitive control (flexibility — rigidity), the "Stroop interference" method was used. A predominant cognitive style characterizes the degree of psychological difficulty in changing the ways that information is processed in situations of cognitive conflict. Rigid control indicates difficulties in moving from verbal functions to perceptive functions because of their low automation degree, whereas flexible control indicates relative ease with such a transition because of their high automation degree (Stroop, 1935).

To analyze success in foreign language acquisition by primary-school children, we have developed a method, "evaluation of the level of foreign language acquisition". This method is based on the approach of structured control. The pupils' activity was observed directly during English lessons, and five main levels of educational material acquisition were determined.

The zero level (Understanding) is the level at which a pupil is able to understand, i.e., to acquire new information consciously. Strictly speaking, this level cannot be called the level of "educational material acquisition" because this concerns the student's background, which allows him to understand the new educational material.

The first level (Identification) is the recognition of the objects and processes in the study during the re-experience of information about them or actions with them that were acquired earlier (for example, the separation of the studied object from the variety of proposed different objects).

The second level (Reproduction) is the representation of the knowledge acquired earlier from imitation to implementation in typical situations (for example, 
information reproduction off the top of the head or solving standard problems using the sample acquired earlier).

The third level (Application) is the level at which a pupil is able to reproduce and transform acquired information by himself for discussion of known objects and the application of the information in unusual situations. In this case, the pupil can generate new information about studied objects and processes (for example, the solution of nonstandard problems or the choice of a proper algorithm from a variety of algorithms studied earlier for the solution of the particular task).

The fourth level (Creative activity) is the level at which a pupil is able to produce new information that is previously unknown to everyone (for example, the development of a new algorithm to solve a problem).

\section{Results}

In the beginning of the study, the pupils were presented with the "comparison of similar pictures" task (J. Kagan). This task was used to diagnose cognitive style with the reaction type "impulsivity - reflexivity". The analysis of the obtained results showed that most of the primary-school pupils aged 8-11 (44 students, or 58.5\% of the participants) demonstrated impulsivity in cognitive activity rather than reflexivity (30 students, or $41.5 \%$ ). This finding might be due to the intensive expression of the cognitive style "impulsivity" when the learning situation is accompanied by difficulties in the study of the subject.

The results of the study of the cognitive style "reflexivity - impulsivity" of the pupils as a function of forms are shown in Fig. 1.

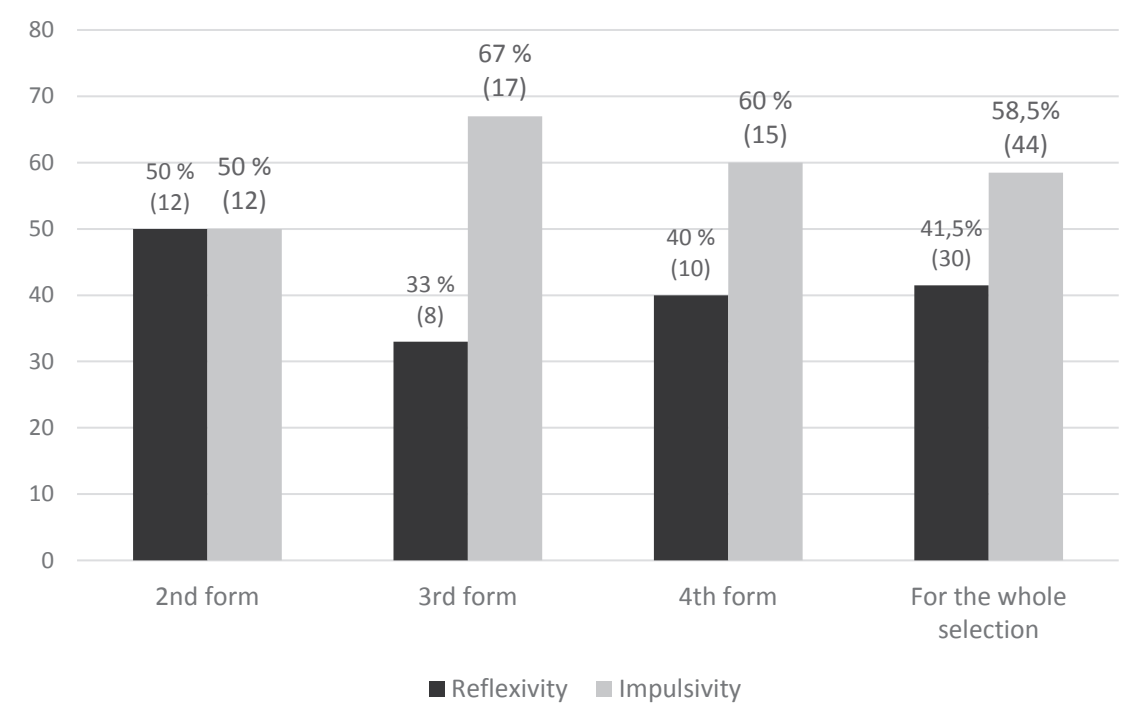

Figure 1. The results of the study of the reaction type "reflexivity — impulsivity" in the primary-school students

It can be seen in Fig. 1 that in the second form, half of the participants (12 pupils aged 8-9) demonstrate the styles "reflexivity" and "impulsivity" on the same 
level. This finding can be explained by the assumption that these cognitive style features are connected not to the method of new material acquisition (at ages $8-9$, an approximate basis of learning activity has only begun to form, whereas the acquisition of new methods of activity is in the process of forming and occurs at ages 9-11) but with the individual typological features of the pupils appearing in accordance with the extent of their mental activity. Quickness and ease of new material acquisition depend on the strength of the nervous system, the predominance of excitation over extinction, a dynamic of the ability to work and fatigability.

However, we can detect the tendency that, during the study of a foreign language, most participants demonstrate the cognitive style "impulsivity" (17 pupils of the third form, aged 9-10 (67\%), and 15 pupils of the fourth form, aged 10-11 $(60 \%))$. These results illustrate the cognitive style features of foreign language acquisition by primary-school students as a new work method: a tendency toward rapid reactions in new situations (the new educational material) and in situations of multiple choice without the analysis of possible solutions. The tested pupils with the impulsive cognitive style can be characterized by word fluency, a high rate of fulfilling separate linguistic tasks, the presence of recurrent errors and stereotypical answers. The children with the reflexive cognitive style differ: they have a slow rate of foreign language acquisition but a higher quality of cognitive activity. Erroneous answers are almost absent, there is no repetition, and solutions are nonstandard.

At the next stage of our study, the students were presented with the "Stroop interference" task, intended to diagnose the ratio of flexibility to rigidity of cognitive control as well as mental flexibility. Fig. 2 presents the results.

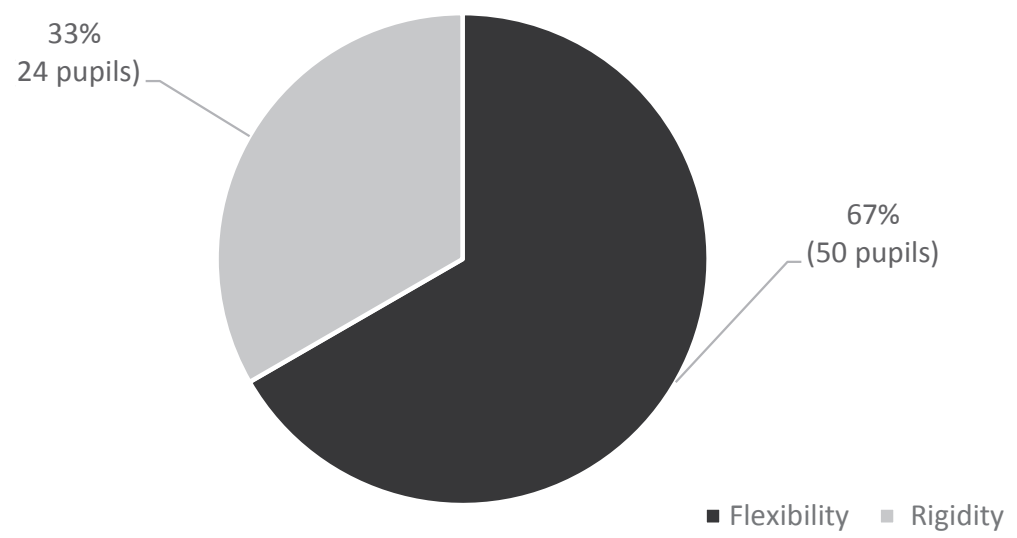

Figure 2. The results of the study of the ratio "flexibility - rigidity" of the schoolchildren's cognitive control

Most of the participants (50, or 67\%) exhibited a flexible style of cognitive control. In this case, a strong automation of the cognitive processes is typical of children with predominant flexible control. However, $33 \%$ of the tested pupils (24 children) had a rigid style of thinking with weak automation of cognitive processes. 
To study the success of foreign language acquisition, the "evaluation of the level of foreign language acquisition" task was used to establish the degree of educational material acquisition, with consideration of the following factors: vocabulary, speaking, grammar, and listening comprehension. Using these factors, a general level of foreign language acquisition was determined.

Analysis of the results shows that level zero (understanding) was found for $25 \%$ of pupils (18 pupils), the first level (identification) was found for most of the participants (50\%, or 37 pupils), the second level (reproduction) was found for $8 \%$ of children (6 pupils), and the third level (application) was found for 17\% (13 pupils). Hence, we can conclude that the level of identification, which is characterized by recognition of the studied objects in the process of re-experiencing information about them that was acquired earlier, is predominant among the primary-school students.

The fourth level (creative activity) was not found at all (0\%). The summarized results of the evaluation of the level of foreign language acquisition are shown in Fig. 3.

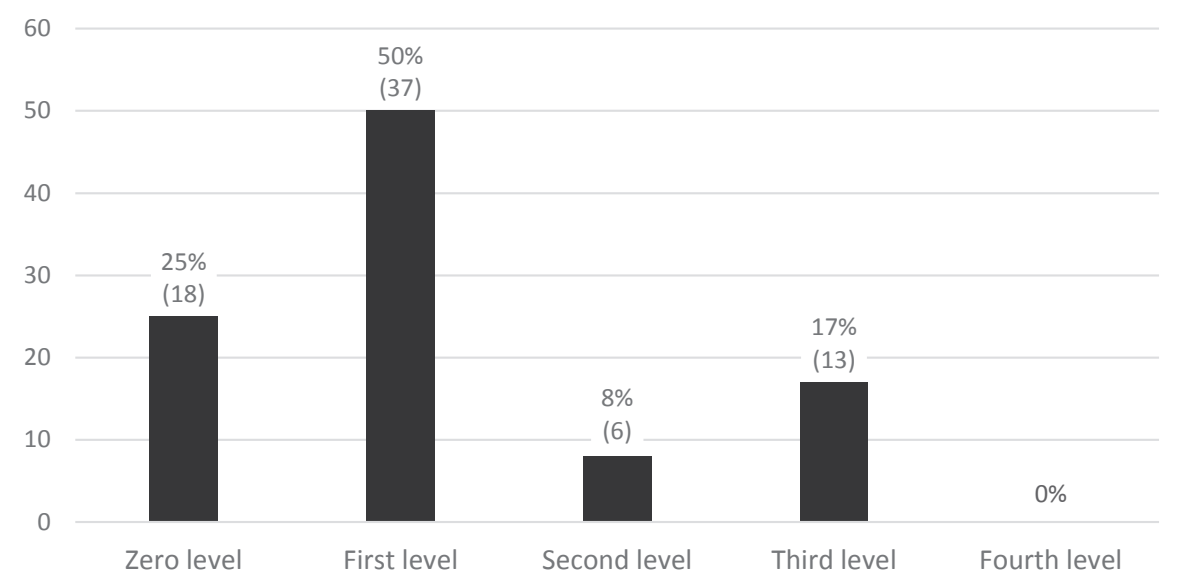

Figure 3. The results of the evaluation of the level of foreign language acquisition

\section{Summary}

A benchmark qualitative study of the obtained results allows us to generalize and to state the following. Impulsive pupils are more successful in foreign language acquisition because they have a flexible style of thinking. Reflexive pupils are less successful because of their individual features and because they are characterized by a rigid style of thinking. These pupils learn the material at the minimal standard level.

To confirm the reliability of the results obtained in the empirical study, we have applied a combination of mathematical methods with the help of the statistical package SPSS 19.0. In particular, to find the connection between success in foreign language acquisition and the individual cognitive styles of the pupils, such as impulsivity - reflexivity and rigidity - flexibility, Pearson's correlation coefficient was used. The results are shown in Table 1. 
Table 1. The correlation of cognitive styles and success in foreign language acquisition by primary school students

\begin{tabular}{lccc}
\hline & & $\begin{array}{c}\text { Reflexivity } \\
\text { Impulsivity }\end{array}$ & $\begin{array}{c}\text { Flexibility } \\
\text { Rigidity }\end{array}$ \\
\hline Vocabulary & Pearson's correlation & $0.718^{\star *}$ & -0.473 \\
& Value (2-sides) & 0.009 & 0.121 \\
& $\mathrm{~N}$ & 74 & 74 \\
\hline Speaking & Pearson's correlation & $0.705^{\star}$ & -0.273 \\
& Value (2-sides) & 0.010 & 0.390 \\
& $\mathrm{~N}$ & 74 & 74 \\
Grammar & Pearson's correlation & $0.761^{\star *}$ & -0.127 \\
& Value (2-sides) & 0.004 & 0.695 \\
\hline \multirow{2}{*}{$\begin{array}{l}\text { Listening } \\
\text { comprehension }\end{array}$} & $\mathrm{N}$ & 74 & 74 \\
\hline $\begin{array}{l}\text { General level of } \\
\text { foreign language }\end{array}$ & Pearson's correlation & $0.779^{\star *}$ & -0.224 \\
acquisition & Value (2-sides) & 0.003 & 0.485 \\
\hline
\end{tabular}

Note: ${ }^{* *}$ - correlation is significant at the 0.01 level; ${ }^{*}$ - correlation is insignificant at the 0.05 level. The levels of critical significance for the Pearson correlation coefficient are $\mathrm{p}_{0.05}=0.576$ and $\mathrm{p}_{0.01}=$ 0.708 (Nasledov, 2012).

The results of the correlation analysis allow us to make the following conclusions.

There is a statistically significant correlation between success in foreign language acquisition and the cognitive style "impulsivity - reflexivity" index at the 0.01 level. This correlation indicates that the more impulsive primary-school pupils are, the more successful they are in foreign language acquisition.

Moreover, there is a significant correlation between the cognitive style "impulsivity - reflexivity" index and the all factors of success in foreign language acquisition. For instance, a significant correlation was found at the 0.05 level between the cognitive style "impulsivity - reflexivity" index and the success factor "speaking". This connection indicates that the more impulsive pupils are, the higher their "speaking" factor is.

A statistically significant correlation was also found at the 0.01 level between the cognitive style "impulsivity - reflexivity" index and success factors of foreign language acquisition such as "vocabulary", "grammar" and "listening comprehension". This correlation implies that the more impulsive pupils are, the larger their vocabulary is and the better they are in grammar and listening comprehension.

A statistically significant correlation between success in foreign language acquisition and the cognitive style "rigidity — flexibility" was not found. 


\section{Discussion}

In this work, we proposed that the important factors of success in primary-school foreign language acquisition are individual styles of acquisition such as cognitive style and the cognitive control that is used in the training process. The results of the present empirical research are similar to those obtained by M. Kabardov (Kabardov, 1983), according to which there are interconnections between the success - failure parameter in foreign language teaching and individual stable characteristics of pupils such as the mental process reaction rate (lability - passivity of mental and language processes). In our research, we study the lability - rigidity parameter. The results of the analysis imply that pupils with a labile nervous system are more successful in knowledge updating and in new information processing, whereas pupils with the passive (or rigid) cognitive type have more advantages in determining logical and grammatical rules in the unknown language.

The comparison of Kabardov's results with our results reveals some discrepancies. According to Kabardov, children with both the labile and passive cognitive types could be successful in foreign language acquisition, but with different parameters. For instance, children with the labile cognitive type are more successful in the acquisition of the communicative components of language, and children with the rigid type are more efficient in language analysis and foreign speech perception. In our research, we have shown that pupils with the rigid cognitive style, in general, are less successful in foreign language acquisition.

We also note a congruence of our results with the claim proposed by I. Zimnyaya (Zimnyaya, 1991) that success in foreign language acquisition by primaryschool pupils depends on "the self-reflection of the language behavior". This claim reflects the statistically significant connections found in this work between the cognitive style "impulsivity - reflexivity" parameter and such success criteria in foreign language acquisition as "speaking" and "listening comprehension".

\section{Conclusion}

The data obtained in this benchmark analysis allows us to make conclusions and generalizations about the connection between success in foreign language acquisition by primary-school students and their reaction type (cognitive styles: impulsivity and reflexivity) and between successful assimilation of the foreign language by pupils and the features of their cognitive control (rigidity and flexibility).

The study has shown that impulsive students are more successful in foreign language acquisition than reflexive students are. For the majority of students, a flexible way of thinking is more typical, and they are successful in the assimilation of the program material in the foreign language. The rest of the students are characterized by the rigid style of thinking. Generally, these are students who learn the material at the minimum standard level.

The statistical analysis of the results allow us to determine a reliable significant correlation between success in foreign language acquisition and the cognitive style factors of the "impulsivity - reflexivity" reaction type. Statistically significant correlations between success in foreign language acquisition and the cognitive control "rigidity - flexibility" index were not discovered. 
On the basis of the foregoing, we can say that at primary-school age, success in foreign language acquisition is greatly dependent on the reaction type (impulsivity - reflexivity) rather than on the type of cognitive control (rigidity - flexibility).

This study has allowed us to consider theoretical and practical problems of success in foreign language acquisition at primary-school age. A consideration of the cognitive style characteristics of pupils, such as the reaction type, allows for the actualization of the personal and communicative abilities of the pupils, to implement the person-centered approach in the learning process, to optimize the learning process and to create favorable conditions for the cognitive development of the pupils.

Prospects for further study may be related to empirical tests of the importance of other cognitive styles during the process of foreign language acquisition by children of primary-school age in modern school conditions.

\section{References}

Adler, A. (2002). Praktika i teorija individualnoj psihologii [Practice and theory of individual psychology]. Moscow: Institut psihoterapii.

Averin, V.A., Kireeva, N.N., \& Kotova, E.E. (2014). Intellektualno-stilevaja organizacija chelove$k a$ [An intellectual and stylistic man organization]. Saint Petersburg, Russia: SPbGPMU.

Barabanshhikov, V.A., Nosulenko, V.N., \& Samojlenko, E.S. (2011). Poznanie v dejatelnosti i obshenii: ot teorii i praktiki k jeksperimentu [Perception in activity and communication: From the theory and practice to the experiment]. Moscow: Institute of Psychology RAS.

Boldyreva, S.V. (2004). Vzaimodejstvie poznavatelnyh stilej i jazykovyh sposobnostej v processe formirovanija jazykovoj kompetencii uchashhihsja: na materiale obuchenija anglijskomu ja$z y k u$ [An interaction of cognitive styles with language capacity in the process of the formation of pupils' linguistic competence]. Tambov, Russia: Tambov State University.

Bunduls, Ja. (1982) Individualnaja psihologija Alfreda Adlera [Individual psychology of Alfred Adler]. Voprosy psihologii [Issues in Psychology], 2, 133-139.

Cattell, R.B. (1971). Abilities. their structure, growth and action. Boston: Houghton Mifflin company.

Ilyin, E.P. (2011). Psihologija individualnyh razlichij [Psychology of individual differences]. Saint Petersburg, Russia: Piter.

Gardner, R.W. (1953). Cognitive styles in categorising behavior. Journal of Personality, 22, 214233. doi: 10.1111/j.1467-6494.1953.tb01807.x

Gardner, R.W., Holzman, P.S., Klein, B.S., Linton, H., \& Spence, D.R. (1959). Cognitive control: A study of individual consistencies in cognitive behavior. Psychological Issues, 1(4), 1-117.

Holodnaja, M.A. (2004). Kognitivnye stili. O prirode individualnogo uma [Cognitive styles. On the nature of individual intellect]. Saint Petersburg, Russia: Piter.

Kabardov, M.K. (2001). Kommunikativnye i kognitivnye sostavljajushhie jazykovyh sposobnostej: Individualno-tipologicheskij podhod [Communicative and cognitive parts of linguistic abilities: Individual and typological approach]. Moscow: Psychological Institute RAE.

Kabardov, M.K. (1983). Rol individual'nyh razlichij $v$ uspeshnosti ovladenija inostrannym jazykom [The role of individual differences of the success in the foreign language acquisition]. (Candidate dissertation). Moscow: Academy of Pedagogical Sciences.

Kagan, J. (1966). Reflection - impulsivity: The generality and dynamics of conceptual tempo. Journal of Abnormal. Psychology, 71, 123-129. doi: 10.1037/h0022886 
Klaus, G. (1987). Vvedenie v differencialnuju psihologiju uchenija [An introduction in differential psychology]. Moscow: Pedagogika.

Klein, G.S. (1970). Cognitive control and motivation. In G. Lindzey (Ed.), Assessment of human motives (pp. 87-118). New York: Rinehart.

Klychnikova, Z.I. (1973). Psihologicheskie osobennosti obuchenija chteniju na inostrannom jazyke [Psychological features of teaching of reading in a foreign language]. Moscow: Prosveshhenie.

Kolga, V.A. (1976). Differencialno-psihologicheskoe issledovanie kognitivnogo stilja i obuchaemosti [Differential and psychological study of a cognitive style and educability]. Leningrad, USSR: Leningrad State University.

Kuljutkin, Ju.N., \& Suhobskaja, G.S. (1971). Individualnye razlichija $v$ myslitelnoj dejatelnosti vzroslyh uchashhihsja [Individual differences in thinking activity of adult students]. Moscow: Pedagogika.

Libin, A.V. (1999). Differencialnaja psihologija: na peresechenii evropejskih, rossijskih $i$ amerikanskih tradicij [Differential psychology over the intersection of European, Russian and American traditions]. Moscow: Smysl.

Messick, S. (1984). The nature of cognitive styles: Problems and promise in educational practice. Educational Psychologist, 19, 59-74. doi: 10.1080/00461528409529283

Nasledov, A.D. (2012). Matematicheskie metody psihologicheskogo issledovanija. Analiz i interpretacija dannyh [Mathematical methods of a psychological study. An analysis and interpretation of data]. Saint Petersburg, Russia: Rech.

Nikitenko, Z.N. (2011). Konceptualnye osnovy razvivajushhego inojazychnogo obrazovanija $v$ nachalnoj shkole [Conceptual basis of developmental foreign-language teaching in primary school]. Moscow: MPGU, Prometej.

Pavlov, I.P. (1951). Izbrannye trudy [Selected works]. Moscow: Academy of Pedagogical Sceinces

Protasova, E.Ju. (2011). Interkulturnaja pedagogika mladshego vozrasta [Intercultural pedagogics of junior age]. Moscow: Forum.

Shhukin, A.N. (2010). Obuchenie inostrannym jazykam: teorija i praktika [Learning of foreign languages: Theory and practice]. Moscow: Filomatis, Omega-L.

Stroop, J.R. (1935). Studies of interference in serial verbal reactions. Journal of Experimental Psychology, 18(6), 643-662. doi: 10.1037/h0054651

Witkin, H.A., \& Goodenough, D.R. (1981). Cognitive styles. Essence and origins: field dependence and field independence. New York: International Universities.

Witkin, H.A., Moore, C.A., Goodenough, D.R., \& Cox, P.W. (1977). Field dependent and field independent cognitive styles and their educational implications. Review of Educational Research, 47(1), 1-64. doi: 10.3102/00346543047001001

Zimnjaja, I.A. (1991). Psihologija obuchenija inostrannym jazykam $v$ shkole [Psychology of foreign language teaching at school]. Moscow: Prosveshhenie.

Zimnjaja, I.A. (2008). Pedagogicheskaja psihologija [Pedagogical psychology]. Moscow: Universitetskaja kniga Logos.

Original manuscript received November 16, 2016

Revised manuscript accepted March 04, 2017

First published online November 30, 2017 